\title{
Proposed Business Strategy for XYZ Consultant Company to Financial Improvement Through Acquisition Strategy
}

\author{
Novi Fitriani and Deddy P. Koesrindartoto
}

\section{ABSTRACT}

$\mathrm{XYZ}$ is a university with the best reputation in Indonesia which has 12 companies engaged in consulting services (construction and nonconstruction)). The proportion of ownership in this business varies from $20 \%$ to $99.99 \%$. This business has several companies that are inefficient and unhealthy because operating costs are greater than revenue. In addition, in 2019, this consulting company experienced a decrease in revenue by $7.11 \%$ while the cost of goods sold increased by $7.45 \%$. This study aims to select which companies have good and healthy performance, create new and effective business strategies for the best performing companies, and develop sustainable business and new competitive advantages. This research methodology is qualitative using secondary data in the form of annual financial reports from 12 companies for 2015-2019, websites and other information media. External analysis in this study using macroeconomics, PEST, Porter's Five Forces, and Benchmark Analysis. While the internal analysis uses Financial Ratio Analysis and Altman-Z Score. The tools used to obtain business solutions and strategies from the XYZ consulting firm case are Business Level Formulations, Business Level Strategies, Functional Strategies, and Implementation Strategies. One of the strategies that the author applies in this case is by implementing an acquisition strategy

After analyzing and calculating using the Financial Ratio and Altman-Z Score of 12 companies, the result shows that there are only 7 companies that have good and healthy performance so that they are included in the "safe zone" category with a discriminant zone $Z>2.99$. The acquisition strategy was created by combining these companies. The first step is to evaluate each company, then calculate the acquisition to find out the synergy value of the acquisition to compare the value when the acquisition was made and what was not. The calculation results show that the company's FCFF accumulation after the next 10 years on 2030, In the event of an acquisition is IDR 124,131,871,981.11. Meanwhile, if there is no acquisition is IDR $117,285,044,723.00$. So that we know there have added value of the synergy IDR 6,846,827,258.11.

Keywords: Business Strategy, Acquisition, Financial Improvement, Consultant Company, Synergy.

\section{INTRODUCTION AND RESEARCH OBJECTIVES}

The impact of Industry 4.0 encourages industry to work and produce quickly in order to compete with its competitors. Consultant services can help every company in developing a business requires planning, strategy, description, and accurate calculations that are close to real value before starting a business or project that will be carried out to minimize losses in the future.

$\mathrm{XYZ}$ has 12 companies engaged in consulting services. $\mathrm{XYZ}$ as owner on this business sector must be able to compete with similar service businesses both at national and international levels because many competitors already have a good reputation in Indonesia and their success in providing services clients.

In addition, the existence of the Covid-19 pandemic this has been very influential in all lines of business sectors in
Submitted : September 28, 2021

Published : March 5, 2021

ISSN: $2507-1076$

DOI: $10.24018 /$ ejbmr.2021.6.2.559

\section{Novi Fitriani*}

Bandung Institute of Technology, Indonesia.

(email: novi.fitriani@ ${ }^{\circledR}$ sbm-itb.ac.id)

Deddy Priatmodjo Koesrindartoto

Bandung Institute of Technology, Indonesia.

(e-mail: deddypri@sbm-itb.ac.id)

*Corresponding Author
Indonesia. A lot of companies are bankrupt and must lay off employees because of their inability to survive in these conditions. This impact is also felt real by the consulting business including XYZ's. So, high business competition makes every company needs to have a clear business model and competitive strategy to win market competition by providing a competitive advantage.

\section{A. Statement of the Problem}

The proportion of ownership of XYZ in this business varies from $20 \%$ to $99.99 \%$. This business has several companies that are inefficient and unhealthy because operating costs are greater than revenue. In 2019, this consulting company experienced a decrease in revenue by $7.11 \%$ while the cost of goods sold increased by $7.45 \%$. In addition, the pandemic Covid-19 virus impact to XYZ's consulting business growth. And many competitors on this sector needs to have a clear business model and competitive 
strategy

\section{B. Research Objectives}

This study aims to select which companies have good and healthy performance, create new and effective business strategies for the best performing companies, and develop sustainable business and new competitive advantages.

\section{RESEARCH METHODOLOGY}

This study approach qualitative methods using secondary data that obtained from Annual Financial Reports from 12 companies from 2015-2019, websites, news, and other information media. Mapping Macroeconomics, PEST, Porter's Five Forces, and Benchmarking Analysis is used in External Analysis. While the internal analysis uses Financial Ratio Analysis and Altman-Z Score. The tools used to obtain business solutions and strategies from the XYZ consulting firm case are Business Level Formulations, Business Level Strategies, Functional Strategies, and Implementation Strategies. One of the strategies that the author applies in this case is by implementing an acquisition strategy.

\section{EXTERNAL ANALYSIS}

External analysis is carried out to determine the opportunities and threats that occur, both in the macroenvironment, industry, and competition. External analysis in this study is carried out through Macroeconomic Analysis, PEST Analysis, Porter's 5 Forces, and Benchmarking Analysis.

\section{A. Macroeconomic Analysis}

The current world economic conditions depend heavily on the impact of the Covid-19 virus pandemic. Many countries have experienced economic downturns to experience recession. Indonesia is one of the countries affected. Based on the results of the projection survey of macroeconomic indicators by Bank Indonesia in the second quarter of 2020 , it shows that the Indonesian economy in 2020, the Indonesian economy is estimated to only grow by $0.03 \%$ (yoy), but this value is lower than in 2019 which reached $5.02 \%$ yoy. Meanwhile, inflation at the end of 2020 is projected at $2.51 \%$ (yoy), lower than $2.72 \%$ (yoy) in 2019 . The exchange rate against USD at the end of 2020 is expected to weaken to the level of Rp. 14,395 per USD compared to the realization at the end of 2019 of Rp. 13,901 per USD [1].

\section{B. PEST Analysis}

\section{Politic}

Indonesia's political stage in 2020 will remain complex. There are at least two important notes. First, it is interesting to note that this year there will be political interests related to the plans of the government and the Parliament in terms of the omnibus law in politics. The DPR and the government are indeed trying to draw up regulations to simplify the Indonesian political system and government through the incorporation of five laws (Laws) into the omnibus law in politics, including Law on Elections, Law on Local Elections, Law on Political
Parties, Law on Legislative Assembly MPR, The DPR, DPD and DPRD (MD3), and the Law on Regional Governments. This plan emerged when the Ministry of Home Affairs consulted with the leadership of Commission II, ahead of the 2019-2024 Prolegnas appraisal.

Second, it is also important to note our political dynamics this year, of course holding simultaneous local elections in 270 regions throughout the archipelago, with details of nine governor elections, 224 regent elections, and 37 mayor elections. This year's local election, involving about 107 million voters or $68 \%$ of the total voter list in the 2019 elections. Thus, it also significantly determines the quality of Indonesia's democratic consolidation now and in the future.

\section{Economic}

The implementation of work from home (WFH), physical distancing, and Pembatasan Sosial Skala Besar (PSBB) during the COVID-19 pandemic to reduce the spread of the virus has caused activities outside the home to drastically decrease. Many companies went bankrupt because of the operating ban which had a domino effect on the laid-off employees. So that people are very careful and have a lot of consideration in using cash or assets. In addition, due to the Covid-19 pandemic, the government must budget funds for subsidies for people who cannot afford it so that it has a domino effect on the economic turnover in Indonesia.

This pandemic has almost paralyzed people's economic activities. Since the government has implemented various policies such as Working from Home, area restrictions, and the closure of various public places such as tourist attractions, many companies or offices have closed their employees. Some middle-lower class entrepreneurs have even laid off their employees in anticipation of the impact of business closures indefinitely.

\section{Social}

As a result of the Covid-19 virus pandemic, various socioeconomic problems have emerged and have a direct impact on society, including:

\section{1) Scarcity of Goods}

The existence of panic buying causes some goods to become scarce on the market. As a result, these goods are sold at many times their original price because there are parties who hoard these items for personal gain. Some items that have become scarce include masks, hand sanitizers, germicidal fluids, and personal protective equipment for medical use.

\section{2) Disorganization and social dysfunction}

If you look at the news that has been circulating recently, there are interesting social facts that have occurred in the community, namely the existence of prejudice and discrimination against Covid-19 victims. This is due to people's fear of uncertain situations due to the spread of the Corona virus. This can be seen clearly from the attitude of the community who keeps their distance when interacting with others, avoids shaking hands, avoids socializing, and so on.

\section{3) Crime}

An economy that does not run as usual causes a group of people with economic difficulties to commit crimes to make ends meet. The crimes committed can be of various kinds, 
such as theft, stockpiling of rare items, making fake hand sanitizers or disinfectants that actually endanger health, fraud in prices for basic necessities, and so on.

\section{Technology}

Technological trends in 2020 such as Artificial Intelligence (AI) are becoming popular technology. This is due to the influence of the growing ecosystem of devices, such as Siri, Alexa, and also Google Assistant. In addition, the Internet of Things (IoT) continues to increase thanks to the emergence of $5 \mathrm{G}$.

The development of this technology will greatly support the consulting business (construction and non-construction) in providing services, for example by means of promotional media and services using websites that can be easily accessed by prospective clients and in supporting the consulting process will provide great opportunities for competing companies.

\section{Porter's Five Forces Analysis}

TABLE I: PORTER'S FIVE FORCES OF XYZ CONSULTANT COMPANY

\begin{tabular}{|c|c|c|}
\hline Threats & Attractiveness & Description \\
\hline $\begin{array}{c}\text { Threats of new } \\
\text { entrants }\end{array}$ & High & $\begin{array}{l}\text { Low barriers to enter } \\
\text { according to law and term, } \\
\text { economic of scale, etc. }\end{array}$ \\
\hline $\begin{array}{c}\text { Bargaining } \\
\text { Power of Buyer }\end{array}$ & High & $\begin{array}{l}\text { A lot of competitor, buyers } \\
\text { sensitive with price, output } \\
\text { of service, do comparation } \\
\text { with other product and } \\
\text { service }\end{array}$ \\
\hline $\begin{array}{l}\text { Bargaining } \\
\text { Power of } \\
\text { Supplier }\end{array}$ & High & $\begin{array}{l}\text { Loyalty of consultant experts } \\
\text { that is difficult to maintain, } \\
\text { demands for salary, career } \\
\text { advancement, employee } \\
\text { health insurance }\end{array}$ \\
\hline $\begin{array}{l}\text { Threats of } \\
\text { Subtitutes }\end{array}$ & Low & $\begin{array}{c}\text { Low of variety of substitute } \\
\text { the product and services }\end{array}$ \\
\hline $\begin{array}{l}\text { Rivalry Among } \\
\text { Exisiting } \\
\text { Competitors }\end{array}$ & High & $\begin{array}{l}\text { A lot of company with good } \\
\text { reputation and brand image, } \\
\text { Every-player have a different } \\
\text { concept, market segment, } \\
\text { uniqueness, and different } \\
\text { service. Now, a lot of small- } \\
\text { medium competitor entry } \\
\text { this industry }\end{array}$ \\
\hline
\end{tabular}

Based on the table above, it can be concluded that this business sector is not attractive, but this sector has an opportunity if the company is able to create the right and appropriate strategy to create unique and different values from its competitors but at competitive prices.

\section{Benchmark Analysis}

In this study, in conducting benchmarking analysis by analyzing foreign, national, and companies at the same level as the XYZ company owned by the university. after collecting data from each company, it is understood that the strategies or important points that have been implemented by each company that can be applied in XYZ's consulting firm are Provides a wide range of consulting services in various sectors; Have certified experts and high education; Speed and accuracy of consulting services is the key; Using various media for promotion such as Website, Facebook, Twitter, Instagram, Youtube, $\mathrm{G}+$, Whatsapp.

\section{INTERNAL ANALYSIS}

\section{A. Financial Ratio Analysis}

Financial ratio analysis has a function to show information about company performance to company management and outside investors. These financial ratios are often used as an analysis tool for profitability, liquidity, debt, and asset management in a company. In this study, an analysis of the financial ratios of $12 \mathrm{XYZ}$-owned consulting companies was carried out by taking data for five years (the company's annual financial statements from 2015 to 2019.

\section{a) Gross Profit Margin}

From the calculation can be seen that from the 12 consulting companies above when compared to the value of gross profit margin in 2019, PT U had the highest value of $29.87 \%$ due to an increase in gross profit in the company from 2018 to 2019 by $7.1 \%$, then followed by PT V at $17.24 \%$ due to an increasing gross profit than in 2018 by $1,4 \%$. As for PT Z and PT Q have a minus value of $-49.04 \%$ and $-15.54 \%$. The company is considered inefficient in utilizing its resources for profit. Meanwhile, PT O has the most consistently increasing gross profit margin over the past 5 years. It shows that the company can maintain business efficiency in generating profits.

At PT Q, there was a drastic decrease in operating income from 2018 to 2019. The decline occurred in Chemical products, which initially in 2018 valued at 5,778,000,000 to $1,314,511,865$. While, in PT Z which experienced a decrease in income from 560,863,637 in 2018 to 313,700,000 in 2019. That was due to a downward trend in sales in the fields of training, survey services, inhouse training services, as well as laboratory equipment rental which is a basic sale in this company.

\section{b) Operating Profit Margin}

Operating profit margin ratio serves to measure how much ability to generate operating income / business from the company's net sales over a certain period of time. When comparing the results of the 2019 operating profit margin calculation among 12 consulting companies, it can be concluded that PT U has the highest ratio of $14 \%$ because PT $\mathrm{U}$ got an increase in projects in 2019 by $4 \%$ from 2018, followed by PT R of $6.5 \%$ because the cost of COGS + operating costs is more efficient than the previous year even though sales are less. Then it can be concluded that the two companies have the ability to generate the largest profits from sales. On the other hand, PT P, PT Q, PT Z were unable to generate profits from the business process because the ratio value was negative at $-539.18 \% ;-175.32 \%$; and $33.72 \%$. In PT P in 2019 there was an increase in operating expense, but operating profit was actually negative because the cost of goods sold decreased from 11,757,355,501 to 99,038,382. In PT Q in 2019 despite a decrease in the cost of sales but an increase in operating expenses from $1,087,966,821$ to $1,113,825,493$.

\section{c) Net Profit Margin}

The calculation results show that PT U has the largest value of $6.95 \%$ and that value has increased for three years in a row. That means this company is consistently able to generate the most net profit. Furthermore, PT R has a value of $6.32 \%$, then PT Z 5.89\%. On the contrary, PT P has a negative net profit margin and has continued to decrease on past three years. And in 2019 the value drops dramatically to 
$-162.91 \%$ due to an increase in operating expenses but operating profit was negative because the cost of goods sold decreased, which caused net profit to be negative. Like-wise, with PT W fell to $-174.54 \%$ in 2019 because the income earned is $882,000,000$ smaller than the cost of goods sold of $1,314,511,565$ so the gross profit value is negative and causes net profit to be negative.

\section{d) Return of Asset}

When comparing the results of the 2019 ROA calculation among the 12 companies, it can be seen that PT $\mathrm{Z}$ has the largest percentage of $26 \%$, then PT R at $16.67 \%$. Both companies showed the ability to convert investment assets into profits very well. On the contrary, PT Z has a declining percentage over the last five years, that in 2019 it reached its lowest point and the value was minus $-187.93 \%$. Similarly, PT W amounted to $-84.06 \%$ occurred due to a decrease in the value of current assets in 2018 amounting to $5,601,631,795$ to $1,763,047,805$. the decrease was from the absence of trade receivables in 2019 for companies while in 2018 the value of receivables reached 4,698,000,00 But the value of the asset does not generate a balanced income.

e) Return of Equity

The calculation table above it can be seen that in 2019 PT $\mathrm{R}$ had a high presentation of $31.20 \%$, then $\mathrm{PT} \mathrm{Z}$ which increased dramatically, because in 2018 the value was negative $(-135.91 \%)$ and in 2019 to be positive $580.10 \%$. Conversely, in PT R, the value continues to decline from 2017 to 2019 . Even in 2019, the value is minus $-228.38 \%$ because in 2019 an increase in the current year profit and loss balance of 1,539,470,103 resulting in a decline in the value of the company's equity. The same thing as PT P, which dropped dramatically from 2018 to 2019 , the value is minus $-8.46 \%$.

\section{f) Current Ratio}

The calculation table above, it can be seen that the company with the highest current ratio in 2019 is PT P. The company was able to increase the value of the current ratio very significantly but was not rational. Because in 2019 it will reach 2726.04 while in 2018 only 1.17 . If the current ratio is too high (value more than 2 times), the company may not use its current assets or short-term financing facilities efficiently. This also shows that there may be problems in managing working capital. But for Creditors, a high Current Ratio is better than a low current ratio, because a high current ratio means companies are more likely to be able to meet debt obligations that are due in the next 12 months.

Furthermore, PT Q with a ratio value of 5.05. Conversely the lowest ratio and the value below one is PT $\mathrm{Z}$, the value is 0.75 , and PT W is 0.42 . While companies whose value has consistently increased over the last three years from 2017 to 2019 are PT V. And in 2019 the value will reach 2.81 .

\section{g) Quick Ratio}

It can be seen that the company with the highest current ratio in 2019 is PT P. The company was able to increase the value of the current ratio very significantly but was not rational. The value reaches 2569.46, while in 2018 only 1.16 . As for the company PT Z the value is 0.75 . Likewise, PT W has a value of 0.42 . A company with a current ratio of less than 1 indicates that the company cannot pay its current liabilities in a short time. These are bad signs for creditors, business partners and investors. While companies whose value has consistently increased over the last three years from 2017 to 2019 are PT V. And in 2019 the value will reach 2.46 .

\section{h) Debt to Equity Ratio}

Based on the results of the calculations from the table above it can be seen that in 2019 PT Y has the largest value, 5.51 followed by PT W 1.72. This company increased during the last three years 2017-2019. Similar with PT X. Most companies such as PT Q, PT R, PT S, PT U, PT V, and PT $\mathrm{Z}$ have ratio values below one. Even at PT $\mathrm{Z}$ value has been negative and has declined over the past three years.

B. Altman-Z Score

Altman-Z score (bankruptcy model) is used as a measurable control tool for the financial status of a company that is experiencing financial distress. The Altman- $Z$ score is used as a tool to predict a company's bankruptcy. This model is expressed in the form of a linear equation consisting of 4 coefficients " $\mathrm{T}$ " because this type of consulting business is a type of non-manufacturing business [2].

The calculation results of the $\mathrm{Z}$ score above, then from the 12 consulting companies can be seen the health of the company in financial terms. The category in the grouping of company conditions consists of 3 groups namely When $\mathrm{Z}>$ 2.99 = "safe" zone; If $1.81<\mathrm{Z}<2.99=$ "gray" zone; and If $\mathrm{Z}$ $<1.81=$ "distress" zone. Among the 12 consulting companies in 2019 , only 7 company that entered the "safe" zone there are PT. O, P, Q, R, S, U, and Z.

\section{BUSINESS SOLUTION}

In this chapter, the author will discuss business solutions that can be applied in the future to 12 consulting firms controlled by XYZ. The business solutions applied to this company are based on the results of external analysis and internal analysis. Based on the analysis result in internal analysis using Financial Performance analysis and calculating Altman-Z scores, it can be seen that from the 12 consulting companies there are only 7 companies that enter the "safe" zone financially and deserve to be considered for the continuation of their business.

\section{A. Business Level Strategy Formulation}

Business-level strategy is defined as a set of integrated and coordinated commitments and actions that companies use to gain competitive advantage by exploiting core competencies in certain product market [3].

Business-level strategy is very important for the company for choose strategy based on customer need [4]. There are key point to selecting a business-level strategy a firm should determine:

\section{1) Who will be served}

Based on segmentation, those who have the potential to become consumers in the consulting business at XYZ are local, global, or international companies ranging from businesses that are developed from small to medium scale up to the top. Surely the company can be a consumer of the street type of service available with the capabilities of XYZ's consulting services. The target market of this company is not only business to business (B2B) but also business to customer (B2C), and also business to government (B2G). 


\section{2) What needs do those target customers have that it will} satisfy

The target that needs to be met by this company in meeting customer satisfaction is to pay attention to operational standards and conditions that must be owned by a consulting company. There are criteria that must have of consultancy services: response time; consultant qualification; consultant history; contract detail, steps, references; and time, related references.

\section{3) How those needs will be satisfied}

There are several criteria that need to be provided and considered by consultants in an effort to maintain the quality of their work including [5]: have the ability and experience similar to the field of expertise, excellent technical, technological, economic, funding, and social culture; have an adequate proportion of qualified experts; can see problems from all aspects and are comprehensive (comprehensive) including in considering factors that affect the performance of consultants and be responsible for solving solutions to problems; the ability to see prospects ahead and can eliminate or minimize existing obstacles; and having skills in planning, formulating, concluding, and communicating the results of their activities properly.

\section{B. Business Level Strategy}

For this consulting companies recommended to use an Integrated Leadership / Cost Differentiation Strategy. This is considered to be related to the business conditions of $\mathrm{XYZ}$ consultants because usually this strategy involves a combination of companies in order to create low cost operational activities while maintaining the product efficiently with several different features from its competitors. Beside that the company is under the control of $\mathrm{XYZ}$ brand as one of the universities that has a very good reputation is considered capable of bringing this company to have a good reputation and brand in the eyes of consumers because consumers also believe that XYZ has highly competent human resources in various sciences that have no doubt. Cost leadership strategies can be achieved by creating efficiency. Through this acquisition, all can be done synergistically so that it can also be done by restructuring by streamlining to minimize employee costs and operational costs.

\section{Functional Level Strategy}

A functional strategy is a strategy that takes into account the internal company in formulating a corporate strategy. The aspects that must be considered for a strategy are financial, operational, marketing, and human resources [6].

\section{1) Financial Strategy}

The functional strategy in this research is discuss the financial projections using Merger and Acquisition Strategy of this consultant company. The results are calculated using the Altman-Z Score from analysis of the 2015-2019 financial statements it can be seen that only 7 companies entered into the "safe zone" in 2019. Based on this analysis, only 7 companies will proceed to acquisition analysis.

Free Cash Flow to the Firm (FCFF) after deducting depreciation \& amortization, change in current assets, change in account payable and accruals, net current asset investment, and net fixed asset investment. From the FCFF, it can be seen that the terminal value of the XYZ consulting firm after 10 years of operation. The terminal value is
Rp.143,064,203,060.46. After that, the estimated value of the present value is obtained from 2020 to 2030 and also accumulated from the FCFF, where if it is assessed for the next 10 years, the FCC value is Rp.124,131,871,981.11. This value is obtained when the condition of the company makes an acquisition by combining the management and operating system of the company with efficiency bases so that the synergy value is obtained. If it is compared with the accumulated FCFF value, if the acquisition is not made and there is no synergy, it is Rp.117,285,044,723.00. The value of FCFF when the company makes an acquisition is greater than the FCFF when the company does not make the acquisition. With this strategy merger or acquisition, the difference in value or synergy value is Rp.6,846,827,258.11.

\section{2) Operation Strategy}

Operational strategy is the planning that the company does in allocating resources that support infrastructure and production. Operations strategy aims to maximize the effectiveness of production and supporting elements while minimizing costs and creating ways for companies to organize the production and sale of goods or services.

After acquisition 7 companies, a synergy is then performed in the operation strategy as follows:

\section{a. Horizontal acquisitions}

Through horizontal acquisition each company can help each other in formulating strategies and achieving the main goal, namely obtaining maximum benefits together. The benefits of carrying out the operation strategy after this merger process are Increased market power, Over-coming entry barriers, Cost of new product development and increased speed to market, Lower risk compared to developing new product, Increased diversification, Reshaping the firm's competitive scope, and Learning and developing new capabilities.

\section{b. Restructuring}

In this study, the consulting firm implemented restructuring with the downsizing method. The downsizing system will be carried out by eliminating a number of work units of the same type of 7 companies that have been acquired, reducing the work units and the number of employees whose tasks are biased and is not directly related to the core business of this consultant.

\section{3) Marketing Strategy}

In this study, to determine the solution of a good marketing strategy used in this XYZ consulting company using the 4P marketing mix.

\section{a. Product}

With a combination of several companies that have different services, it can be an additional power for the company to get a wider market size. There are recommendations for strategies that can be applied to consulting service products: (1) XYZ consulting company must be able to understand what varies products the market needs. To understand market needs, not only product information is sought but also requires the right strategy to be able to market these products, Formulate a standard operational service (SOP) for consulting services as expected by consumers, which are usually fast, accurate, clear, and reliable, Provide training to all levels of workers, especially expert consultants on service regulations that are in accordance with the SOP, good, correct, effective, and 
efficient, Packaging the types of products and services available is rather attractive and convinces consumers.

\section{b. Price}

Pricing for consulting services in Indonesia by the government is based on minimum standards controlled by the National Association of Indonesian Consultants or Ikatan Nasional Konsultan Indonesia (INKINDO) in 2019 in order to meet the needs of national consulting service companies to compile price quotes ( 9 proposed prices) and can be used by consultant service users as a reference in compiling Budget Plan (RAB) and self-estimated prices for consulting services business activities. In addition to implementing a pricing strategy based on the provisions made by INKINDO, $\mathrm{XYZ}$ consulting firms can also implement the following strategies: Seek information regularly about products that are needed by the market today, looking for detailed information on the price of consulting services provided by competitors, and providing bundling packages for large, long-term, and sustainable project types to create a symbiotic mutualism between companies and consumers

\section{c. Place}

On this strategy each company continues to optimize its existing offices and facilities to provide services to its customers. The recommendation for this strategy is Optimizing available office functions so that every customer can be served properly and optimally, Making the existing office as a medium for developing company promotions, and creating a comfortable, conducive and safe office atmosphere for potential customers.

\section{d. Promotion}

Here are some strategies that can be applied to increase consumer brand awareness of the company, products and services, capabilities, and company advantages: Creating websites and social media accounts such as (Facebook, Instagram, Twitter, LinkedIn, Google+) for companies that do not have promotional media and information for potential consumers in using consulting services and increasing brand awareness of potential customers, Developing websites and social media for companies to be informative, eye catching, and easy to use, and join seminars or training for companies that are potential target markets by providing knowledge in areas of expertise in consulting services but with a promotional mission to introduce the company, products, services, and the advantages of this company.

\section{4) Human Resource Strategy}

Apart from restructuring and downzoning, the following strategies can be applied to increase the efficiency and effectiveness of the company: Organizing optimal competency training for the executive, staff, and structural levels with the aim of increasing HR Competence, especially those directly related to the consulting service process; Organizing optimal competency training to improve HR competencies that are directly related to marketing processes and products; Make optimal use of the quality of employees who are under 35 years of age because they have the ability to complete work faster; and Transferring knowledge through collaboration with competent parties in the fields required by XYZ.

\section{Implementation Strategy}

In making an implementation strategy for this consulting firm at XYZ, the author uses The Diamond Strategy tool.
The strategy element in diamond strategy includes 5 things, there are:

\section{a. Arenas}

The XYZ's consultant will be a leader in consulting business in the fields of construction, non-construction, electrical, water and environmental, engineering, and IT. The target market segmentation is companies with fields related to consulting expertise in $\mathrm{XYZ}$, startups for the developing stage, government agencies, non-government organizations, private institutions that are running a project.

\section{b. Vehicle}

To achieve the objectives of the above planning, XYZ consulting companies can realize internal growth, namely by maximizing the potential of each company such as utilizing existing office facilities to be able to serve consumers maximally, utilizing existing website platforms to present information and promotions. for customers, improve the performance of social media accounts, YouTube channels to increase the company's brand image of customers.

\section{c. Differentiators}

On achieving this success, the XYZ consultant can choose the best combination strategy of differences to show uniqueness and the effect of cost leadership. XYZ consultants by implementing integrated a business differentiation and cost leadership strategy have service characteristics with certified experts, a higher education background and also a lot of experience, quality and speed of service in completing projects on time. Price option rates and payment systems according to the type of project being carried out and consumers can choose according to their needs, the quality of the consultation and analysis results can be trusted.

\section{d. Stages}

On this strategy the companies create 5 years plan to apply several strategies such as R\&D (Market Research Development), Marketing Promotion, Develop and evaluate website platform, Restructuring with downsizing method, and Direct sales.

\section{e. Economic Logic}

At this stage the XYZ consultant is expected to get a profit whose value is above the cost of capital. There are steps that can be taken by XYZ consultants are to increase the economic scale of the company which was initially limited with local customers to national and even international. Furthermore, the efficiency of the company by making acquisitions then restructuring with the application of downsizing. In addition, this company also generates revenue from direct costs, consignment, and joint exhibitions, training, or seminars so that it can increase its output level. XYZ consultants apply a combination of the lowest cost through scale advantages and premium prices due to proprietary product features. As for the features possessed by XYZ, namely experts and experiences, the quality and speed and accuracy of the analysis can be trusted.

\section{CONCLUSION}

To Develop a sustainable business strategy and create new competitive advantage in order to effectively increase the profit of the company, there are the proposes several strategies such as: uses the Integrated Cost 
Leadership/Differentiation Strategy, Horizontal Acquisition Strategy, Restructure with downsizing method, apply marketing mix 4P, and acquisition strategy.

After calculating using the Financial Ratio and Altman-Z Score the results show that there are only 7 companies that have good and healthy performance. Then the acquisition calculation is carried out to find out the synergy value of 7 companies. The calculation results show the company's accumulated FCFF after the next 10 years (2030), if an acquisition is made, it is IDR 124,131,871,981.11. Meanwhile, if the FCFF acquisition is not carried out, the accumulation of the next 10 years (2030) is $\mathrm{Rp}$. $117,285,044,723.00$. Then there is a difference that shows the value synergy of Rp. 6,846,827,258.11.

\section{REFERENCES}

[1] Bank Indonesia website. (2020). Macroeconomic Data: GDP, Inflation, Rupiah exchange rate. https://www.bi.go.id/id/moneter/inflasi/data/Default.aspx.

[2] Altman, Edward I. (2000). Predicting Financial, Distress of Companies: Revisiting The Z-Score and Zeta ${ }^{\circledR}$ Models. New York University. Stern School of Business.

[3] Hough, J. R., \& White, M. A. (2003). Environmental dynamism and strategic decision-making rationality: an examination at the decision level. Strategic Management Journal, 24(5), 481-489. http://doi.org/10.1002/smj.303.

[4] Hiit, M.A., Ireland, R. D., \& Hoskisson, R. E. 2016. Strategic Management: Competitiveness and Globalization 11e. Canada: Cengage Learning.

[5] Dewi Dharu. (2007). Peranan Industri Jasa Konsultan Nasional Untuk Mendukung Program PLTN Pertama di Indonesia. Pusat Pengembangan Energi Nuklir. BATAN.

[6] Hitt, Michael A., Ireland, R. Duane and Hoskisson, Robert E. (2009). Strategic Manajement: Competitiveness and Globalization, Edisi Bahasa Indonesia, Jakarta, Salemba Empat.

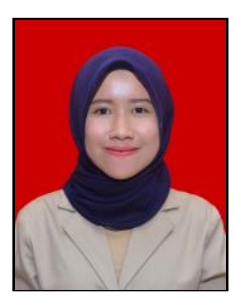

Novi Fitriani was born on February 5, 1995, in Bandung, West Java, Indonesia. She earned a bachelor's degree from Padjadjaran University in 2017 majoring in Animal Husbandry Faculty with major Social Economic in Agriculture.

She is currently pursuing her master's degree in Master of Business Administration at Bandung Institute of Technology, Indonesia.

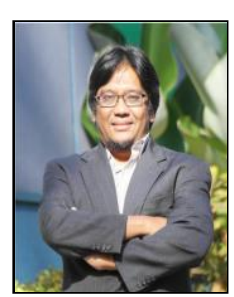

Deddy Priatmodjo Koesrindartoto earned his $\mathrm{Ph} . \mathrm{D}$. in Economics with a minor of Statistics, and an MSc. In Industrial Engineering, all from Iowa State University. He also earned first degree in Electrical Engineering from ITB, Bandung. He is an Assistant Professor at the School of Business and Management, Institut Teknologi Bandung (SBM ITB).

He was the former Director of Graduate Programs of Management Science in SBM ITB, oversees both Master and PhD Programs. Before that assignment, He served as Director of Institutional Development and Planning at SBM ITB. Currently Deddy is the Head of Capital Market and Investment Laboratory and the Head of Kresna - SBM ITB Financial Trading Center, School of Business and Management ITB. Prior to joining SBM ITB in 2005, He was a Research Fellow at the Center for Computational Finance and Economics Agents (CCFEA) at the University of Essex, UK. He spent three years working for energy services industries before pursuing graduate studies. 